\begin{tabular}{c} 
Volume and Issues Obtainable at Center for Sustainability Research and Consultancy \\
Journal of Accounting and Finance in Emerging Economies \\
ISSN: 2518-0318 ISSN (E) 2518-8488 \\
Volume 6: Issue 2 June 2020 \\
CSRE \\
Journal homepage: www.publishing.globalcsrc.org/jafee \\
\hline
\end{tabular}

\title{
Violence Experienced by the Girls with Hearing Impairment in the Schools and its Impact on their Education
}

\section{${ }^{1}$ Samina Ashraf, ${ }^{2}$ Rukhsana Bashir, ${ }^{3}$ Ghulam Fatima}

${ }^{1}$ Assistant Professor, Department of Special Education, University of the Punjab, Lahore-Pakistan, miss_saminadse@yahoo.com

${ }^{2}$ Assistant Professor, Department of Special Education, University of the Punjab, Lahore-Pakistan

${ }^{3}$ Associate Professor, Institute of Education and Research, University of the Punjab, Lahore-Pakistan

\begin{abstract}
ARTICLE DETAILS
History

Revised format: May 2020

Available Online: June 2020

\section{Keywords}

Violence, Hearing impairment, Academic performance.
\end{abstract}

\section{JEL Classification}

$I O, I 2, I 3$

\begin{abstract}
School based violence is a type of youth violence that occurs within school premises. A students can be a victim, perpetrator or a witness of school based violence. The incidence of violence prevails more among girls with hearing impairment due to their communication and language problems. The main objectives of conducting this research were to explore the nature and type of violence experienced by the girls with hearing impairment studying in the schools of Punjab, highlight the impact of violence on their academic outcomes and to see the role of school administration for the rehabilitation of victimized girls. A qualitative research design was used to conduct the study. The population of the study consisted of girls with hearing impairment studying at secondary level in the schools of Punjab province. A sample of 17 girls with hearing impairment was purposively selected from the 17 schools of Punjab. Researchers took only those girls who had been victim of violence once and more in their life during school hours. An interview protocol was developed to take interview in-depth interviews from the victimized girls. Based on the interviews, violence experience by the girls characterized into four themes including physical, psychological, sexual and verbal abuse. The study concluded that all types of violence effects on the overall personality and in particular on the academic performance of victim. The study highlighted that schools have not any formal system to deal the violence related issues. Study recommended for the empowerment of girls with hearing impairment to raise their voices against violence.
\end{abstract}

\section{OPEN ACCESS}

(C) 2020 The authors, under a Creative Commons AttributionNonCommercial 4.0

Corresponding author's email address: miss saminadse@yahoo.com

Recommended citation: Ashraf, S., Bashir, R. \& Fatima, G. (2020). Violence Experienced by the Girls with Hearing Impairment in the Schools and its Impact on their Education. Journal of Accounting and Finance in Emerging Economies, 6(2), 547-557 


\section{Introduction}

Hearing impairment is an impairment in hearing or listening, whether permanent or fluctuating that adversely affects a child's academic performance. It can be classified into two groups; hard of hearing and deafness (Moores,2006).In Pakistan total number of persons with disabilities is 2.49 (Census report,1998) and the total number of persons with hearing impairment is 39\% Hearing impairment or hearing loss adversely affects the lives of persons with hearing impairment and they face many problems. Speech and communication problem is the most significant which leads towards the psychological problems and social isolation (Moores, 2006; Paul, 2000).

Many researchers believe that usually girls, particularly girls with disabilities are at high risk of all types of abuse including verbal, physical, psychological and sexual including institutional violence, drug use and medical abuse (Khan\& Fatima, 2015). Girls with hearing impairment experience violence for an extended time period and grieve more severe injuries as a result of the violence (Ortoleva \& Lewis 2012). According to Broderick (2012) the risk of violence increased when culprits are care takers, or who are in a situation of control and influence, or if they are having shared accommodation services.

Women and girls with disabilities also experience violence that is specific to the nature of their disability. This can include, denial of mobility and communication devices, withholding of food or medication, or exploiting a woman in order to access her support services (Dillon, Hussain, Loxton \& Rehman, 2010). Research regarding the occurrence of violence against girls with hearing impairment is very limited and scrappy. Much of the literature on violence seems to focus predominantly on sexual abuse and mainly related to persons with intellectual disabilities (Jaysingh, Jaywardena , \& Perera, 2009).

However, some of the research studies have discussed the violence experienced by the girls with hearing impairment in school settings as most frequent form of violence. Olweus et. al (2010) and Smith and Brain (2000) have defined it as a relationship of unequal power between young perpetrators who are involved in frequent abusive and aggressive behaviors towards victim. Girls with hearing impairment are the frequent targets of physical and or psychological teasing, name-calling, hitting, pushing, social exclusion, threats, beating by teachers or class fellows, emotional extortion, and theft with in the schools (McCarthy,2001).

Talking about violence in school settings, Sullivan (2006), Weiner \& Miller (2006) stated that the incidence of violence prevails more among girls with hearing impairment due to their communication and language problems. Oosterhoorn and Kendrick (2001), Westcott and Jones (1999) found communication difficulties and use of nonverbal communication as one of the leading factors that increase the risk for sexual assault among girls with hearing impairment.

A largely neglected aspect of school violence is low-level, underlying violence in schools that includes bullying, peer sexual harassment, victimization based on sexual orientation, and the psychological maltreatment of students by teachers(Khoury-Kassabri, 2019). Low-level violence angers and alienates many students and contributes to a hostile school environment (Dupper \& Adams 2002). School based violence effect largely on the academic outcomes of the victimized students(Bond et al., 2007)

Pakistani society avoids discussing this problem by viewing this problem as random. It is observed that Pakistani women of every class either educated or uneducated experience broad categories of violence including physical, sexual psychological and emotional abuse both in home and in the school. This study is an effort to highlight the issue of at the school violence faced by the girls with hearing impairment with in Pakistani context.

\section{Background of the Study}

Women and girls everywhere are disadvantaged in terms of social power and influence, control of resources, control of their bodies and participation in public life (Taiwo, 2019), as a result of socially determined gender roles and relations. Violence against women and girls is also comes under, gender-based violence (GBV) is widespread(Davies $\&$ True, 2015). It is estimated that, worldwide, $30 \%$ of ever-partnered women aged 15 years and older have experienced physical and/or sexual violence in their lifetimes. In addition to health and physical impacts violence also have negative social and economic impacts on survivors and their families(Macmillan, 2001) which ultimately effect 
on the education and careers of victimized girls(Macmillan \& Hagan, 2004). Many international studies have highlighted the incidence of violence in the schools (Thornberg, 2011) particularly in schools where girls with disabilities are enrolled(Dupper \& Meyer-Adams, 2002) need to be counter due to its devastating impacts on the lives of victimized students . Another study conducted by (Han et al., 2019) has found prevalence of violence in the schools as at alarming level for the overall performance of young adolescent school going girls(van der Heijden, Abrahams, \& Harries, 2019).Besides the lifelong negative effects of violence leaving on the lives of girls with hearing impairment, much of the research has not focused on listening the victimized girls violence related experiences.

\section{Implications of the Study}

There are multiple implications of this study. First, the study will be helpful in highlighting the nature of school based violence experienced by the GWHI and will explain the impact of violence on the education of girls with hearing impairment (GWHI) in our local scenario.

By providing ample explanation of school based violence, faced by the girls with hearing impairment in schools of Punjab, the parents of the victimized girls would become more conscious about the security of their girls with hearing impairment even inside the schools. The school administration of other schools of girls with hearing impairment could be able to reconsider their school security system to protect the girls with hearing impairment from further incidence of violence.

Teachers can also get benefit from this by taking guidance from the interview findings narrating the experiences of girls with hearing impairment regarding exposure to different forms of violence with in classroom premises. Teachers would be able to counter the violence being perpetrated by them. It may reduce the phenomena of violence in the society by exposing the leading causes of school based violence. The researchers hope that the findings of the study would inform the stakeholders about the characteristics, factors, and impacts of violence against girls with hearing impairment occurring within school settings. It will further highlight the nature of the measures that the teachers of victimized girls with hearing impairment are taking and had taken in helping them to cope with the adversities of violence. This will be of enormous significance for the stakeholders to take the peculiar circumstances of the area into account in devising and implementing case specific intervention plans. This study will help as a reference for further research in the areas of violence against girls with hearing impairment in other parts of Pakistan in general.

\section{Objectives of the Study}

Specifically, the research was conducted to achieve these objectives:

1. Explore the types of violence experienced by the girls with hearing impairment studying in the schools of Punjab.

2. Highlight the impact of violence on the education of the girls with hearing impairment after experiencing the trauma of violence.

\section{Questions of the Projects}

The questions of the study was following.

1. What are different types of violence experienced by the girls with hearing impairment studying in the schools of Punjab?

2. What is the impact of violence experienced by the girls with hearing impairment on their education?

3. What type of measures teachers are taking to address the issue of violence in their schools.

\section{Methods and Procedures of the Study}

Both Quantitative \& Qualitative research methods were used to conduct the study.

\subsection{Population}

The population of the study consisted of girls with hearing impairment studying in the schools of Punjab province in grades 6 to 10 and their respective teachers. The total number of population of hearing impaired girls studying in the schools of Punjab, who are studying in the 34 school in total 31 districts of the Punjab, is 6164. 


\subsection{Sample of the Study}

The researchers selected the 17 schools (50\% of total population) randomly out of 34 schools. A survey was conducted to identify the cases of violence occurred in the schools. Only those girls with hearing impairment were selected who had experienced any type of violence in the school. Finally a number of (17) seventeen girls from grade 6 to 10 have shown their willingness to participate in the study and share their violence related experiences. A number of 50 teachers were also selected purposively from 17 schools, where the cases of violence were reported.

Two different types of instruments were developed to collect the data; a close ended questionnaire comprised of 16 questions, (12 dichotomous and 04 multiple type), for the interview of the teachers and an interview protocol was developed to take interview from the girls who had experienced violence.

Validity of the instruments were estimated by experts' opinion. Pilot testing was conducted to check the reliability of the close ended questionnaire, which was .807 , measured by Cronbach alpha. Present research was conducted into two phases. At first, the researchers conducted in-depth interviews of the girls with hearing impairment. An in-depth interview involves a one-to-one conversation between interviewer and interviewee and is a tool of data collection used in qualitative research. The duration of each interview was 50 to 90 minutes. Sign language interpreters were used for the clarity of communication of victimized girls with hearing impairment. Before conducting interview rapport was established between interviewer and interviewee. A survey through questionnaire was also connected to get the opinions of the teachers to explore the measures taken by them for the rehabilitation of victimized girls.

\section{Data Analysis}

The data were analyzed by using two types of techniques. The interviews of the teachers were analyzed by using SPSS. Whereas the in-depth interviews of the victimized girls were analyzed through thematic analysis by using interpretive approach of qualitative research. The recorded interviews were professionally transcribed by the researchers. Each transcript was reviewed for accuracy against the recording and coded. Utilizing a content analysis approach, the interviews were completely coded, and a list of codes that focused on key areas of interest were generated. On the basis of codes, four broader themes were appeared at the final stage of data analysis.

\section{Findings of the Study}

Findings based on the interviews of girls with hearing impairment gave rise four broader themes. These themes have been presented along with voices of victimized girls.

\subsection{Physical Violence}

In case of this study, physical violence also takes the shape of harassment as reported by the cases interviewed. Out of 17 cases, the perpetrators were teachers ( 2 cases) and non-academic staff of the schools, i.e. bus driver and peon ( 07 cases) and class fellows (8 cases). By describing the nature of physical violence, a girl with hearing impairment expressed that;

My teacher use to put slap on my shoulder or back, some time she also hit me with note book or book, which really hurt me physically and mentally... she also twist my ear in extreme anger.

A girl having tears in her eyes narrated as

My class fellows are used to push, kick and hit me, and pull my hairs too, mostly in break times and when teacher is absent. I have file complain many times from my class teacher but she always asked to ignore such actions of class fellows.

Schools are places where girls should feel protected and safe. The school supervisors, should feel their duty to provide a secure environment that facilitates and promotes students' self-respect and progress. However, respondents of this study have expressed that schools have the excuse of "discipline" in case of corporal punishment. Abuse at school affects not only these girls' mental health and self-esteem, but also their desire to go to school and to acquire academic skills. Students abused at school tend to drop-out and become untrained, uneducated, unemployed citizens full of resentment and anger, and likely to engage in anti-social behaviour. Sometimes, neither the child nor the perpetrator considers an abusive act as unusual or reprehensible. The victim feels guilty and ashamed, thinks that the violence was deserved and is embarrassed to report it. 


\subsection{Verbal Violence}

Verbal violence has emerged as an important theme out of in-depth interviews of girls with hearing impairment. Requesting repeatedly for dates or sexual favors in person or through text, making explicit comments on girls' dressing or passing unnecessary comments, on any one's body part or physique, while passing by and threatening to harm the person in case of non-cooperation are verbal form of violence or harassment appeared in this study (Stark 2015).

14 out of 17 girls have expressed that they are victim of verbal violence on frequent basis. Whereas, rest experienced it occasionally. A GWHI expressed it as

I am victim of my class teacher verbal abuse us while talking with her colleagues, both in spoken and sign language. Although, I can't hear but can read their facial expressions and gestures.

One more GWHI expressed as

My class fellows and bus conductor, use to make fun of mine, I am not completely deaf, I can hear their laughter, can read their faces and see their sign, ridiculing me on my physique and physical features. I wish if I could have speak, I could have teach them a lesson. It disturbed me so much that could not concentrate on my studies and I have tried many times to leave the school.

\subsection{Sexual Violence}

The girls with hearing impairment have reported sexual violence as worst type of violence experienced in the school settings. WHO(2018) has described it as any sexual act, attempted to obtain a sexual act, unwanted sexual comments or advances, or acts to traffic, or otherwise directed, against a person's sexuality using coercion, by any person regardless of their relationship to the victim, in any setting, including but not limited to home and work.

In this study none of the case has reported for forced rape with in the school premises, however, the incidences of bad touches, attempt to obtain sexual act and unwanted sexual comments including gestures have been reported by the participants of the study.

One of the GWHI reported sadly that

Since I got admission in school, I feel so insecure, as every male around me scared me, watched me with lusty eyes, and tried to get so close to me. Once a bus conductor offered me to sit beside him, after my refusal, he has started harassment and sometimes he want to touch me. What is my fault if I am girl? All this disturb me so much that I want to leave the school? I feel insecure in school.

Another teenage girl expressed in these words that

I can't told you exactly about the attempts my class fellows have mad to touch my body parts, but they attempted so frequently after school timings and in the absence of teachers...that it scared me from school. Who has given them this right, they should be punished as it effect my grades and exam results so badly. I can't tell anybody, not even my parents. They will blame me. I know.

While describing about an attempt to involve in sexual act by some one GWHI stated

I was badly disturbed after all that happened....every one trying to catch me and no one believe me. I am still

having bad mental condition unable to focus on anything, particularly on my studies.

That girl hide the identity of perpetrator too.

\subsection{Psychological/Emotional Violence}

All types of abuses weather physical, sexual or verbal have psychological or emotional effects on the victims. (Stark 2015).In the cases investigated in this study all victims went through the two main cycles, first the tension building, then the threatening, all cases mentioned that they started blaming themselves for what was happening to them.

One of the GWHI expressed that

Whenever, anybody abuse me, it heart badly my feelings and thoughts about me and about the world around me, it is so tense to know somebody don't respect you as human being. Getting stressful does not harm others, rather, it effect on your personality, your academics and many things.

Case 2 mentioned that she started to feel that all of this is happening to her because of her disability and case 3 went into isolation and was unable to perform activities of life. 
For all the cases the situation led to personality disorders they reported that it affected their confidence to do anything after this and they were too ashamed of themselves. They also reported that their physical health also got affected which effect on their academic performance. All of them faced isolation from the family, case 4 mentioned that only her mother supports her when she was in psychological stress and depression. All cases reported significant effects on their academics due to psychological trauma.

Table No.1: Frequency / percentage and nature of violence experienced by the GWHI

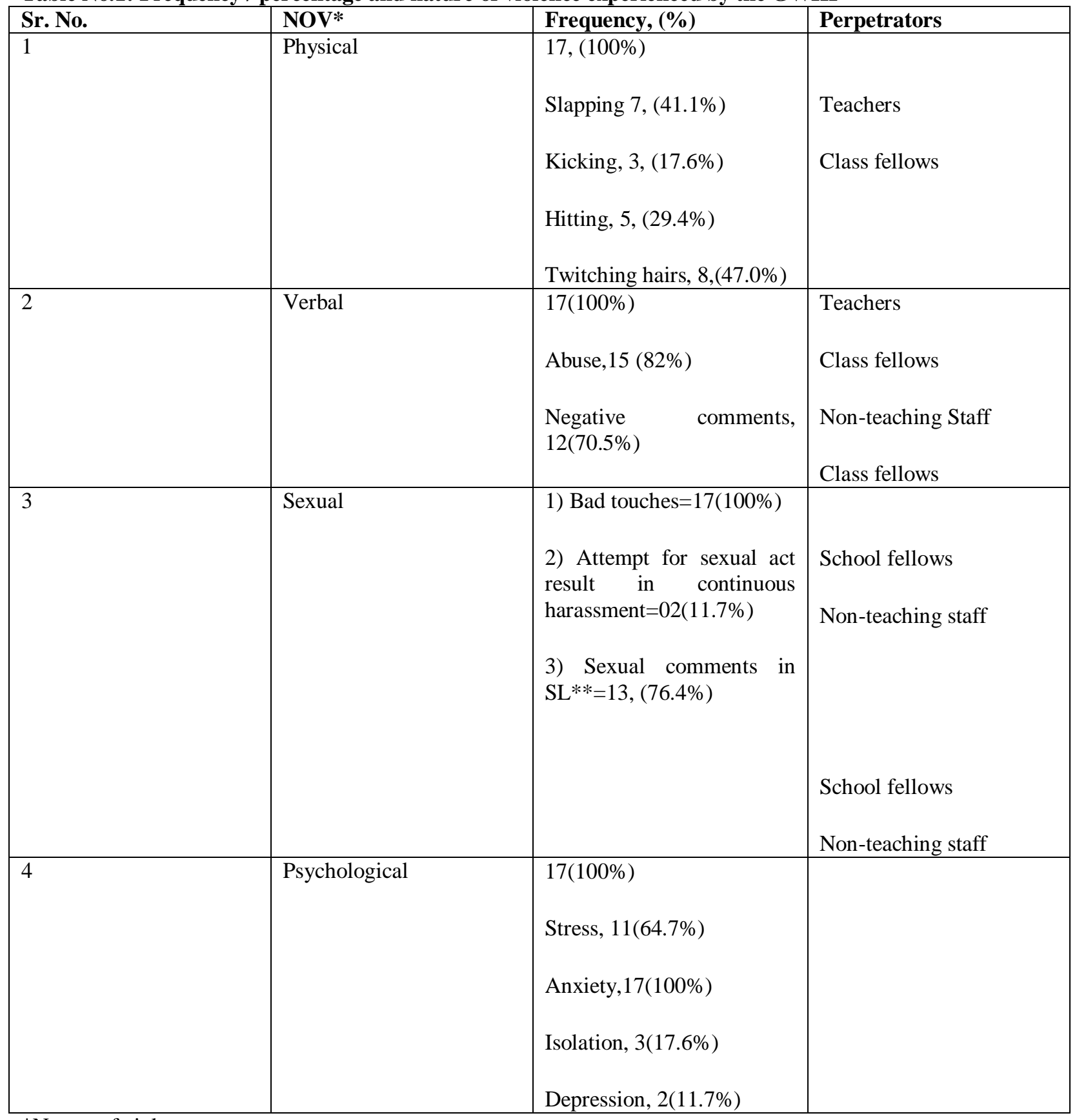

*Nature of violence

$* * \mathrm{SL}=$ Sign Language

To see the measure teachers are taking to deal the issue of violence, 50 teachers were interviewed. The frequency and percentages of the teachers against each responses were calculated and presented in the table No.2. 
Table No.2: Reponses of teachers against questions

\begin{tabular}{|c|c|c|c|}
\hline Sr. No & Questions & Yes & No \\
\hline 1 & $\begin{array}{l}\text { Do you ever received any complain } \\
\text { regarding any harassment incident with any } \\
\text { girl of school? }\end{array}$ & $11.8 \%$ & $88.2 \%$ \\
\hline 2 & Do you tell the parents about the victim? & $10 \%$ & $90 \%$ \\
\hline 3 & Do you involve police? & $0 \%$ & $100 \%$ \\
\hline 4 & $\begin{array}{l}\text { Do you demand the medical history while } \\
\text { appointing male staff? }\end{array}$ & $70 \%$ & $30 \%$ \\
\hline 5 & $\begin{array}{l}\text { Do you demand psychological history from } \\
\text { male staff while appointing them? }\end{array}$ & $0 \%$ & $100 \%$ \\
\hline 6 & $\begin{array}{l}\text { Do the incident impact on the educational } \\
\text { performance of the victim? }\end{array}$ & $100 \%$ & $0 \%$ \\
\hline 07 & $\begin{array}{l}\text { Do the incidents effects the victimized girls } \\
\text { psychologically? }\end{array}$ & $70.6 \%$ & $29.4 \%$ \\
\hline 08 & $\begin{array}{l}\text { Do any programs is being arranged by the } \\
\text { government or school administration to train } \\
\text { the staff to control these types of incidents? }\end{array}$ & $20 \%$ & $80 \%$ \\
\hline 09 & $\begin{array}{l}\text { Do you support the victim to come back to } \\
\text { her normal life? }\end{array}$ & $29.4 \%$ & $70.6 \%$ \\
\hline 10 & $\begin{array}{l}\text { Does such incidents caused drop out of } \\
\text { victimized girls from school? }\end{array}$ & $40 \%$ & $60 \%$ \\
\hline 11 & $\begin{array}{l}\text { Do you have any counseling center in school } \\
\text { to deal specifically violence related issues? }\end{array}$ & $23.5 \%$ & $76.5 \%$ \\
\hline 12 & $\begin{array}{l}\text { Do you think School based violence has been } \\
\text { increased from the past }\end{array}$ & $80 \%$ & $20 \%$ \\
\hline
\end{tabular}

Table No.3: Responses of teachers on measures taken by them to rehabilitate victim. $N=50$

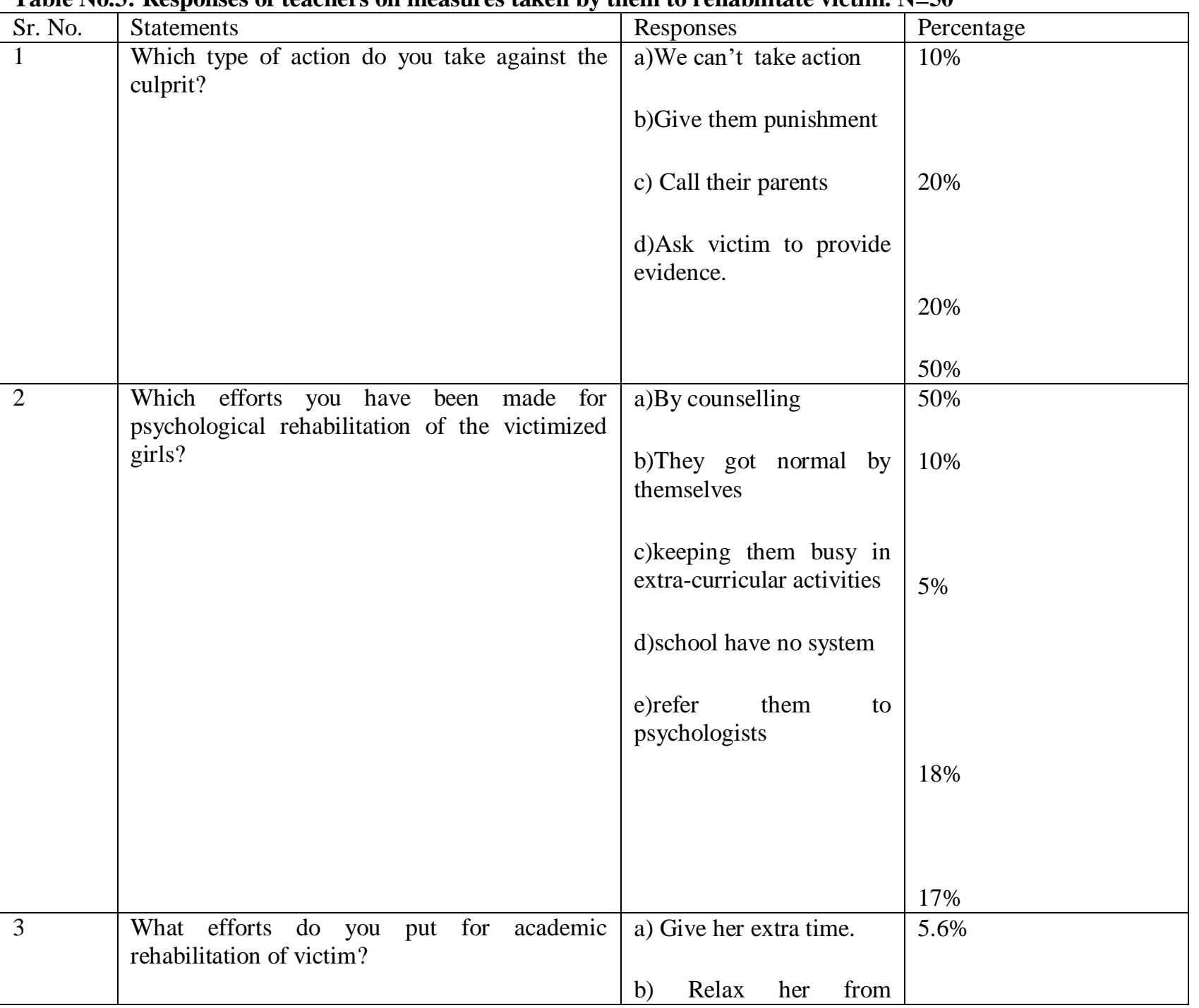




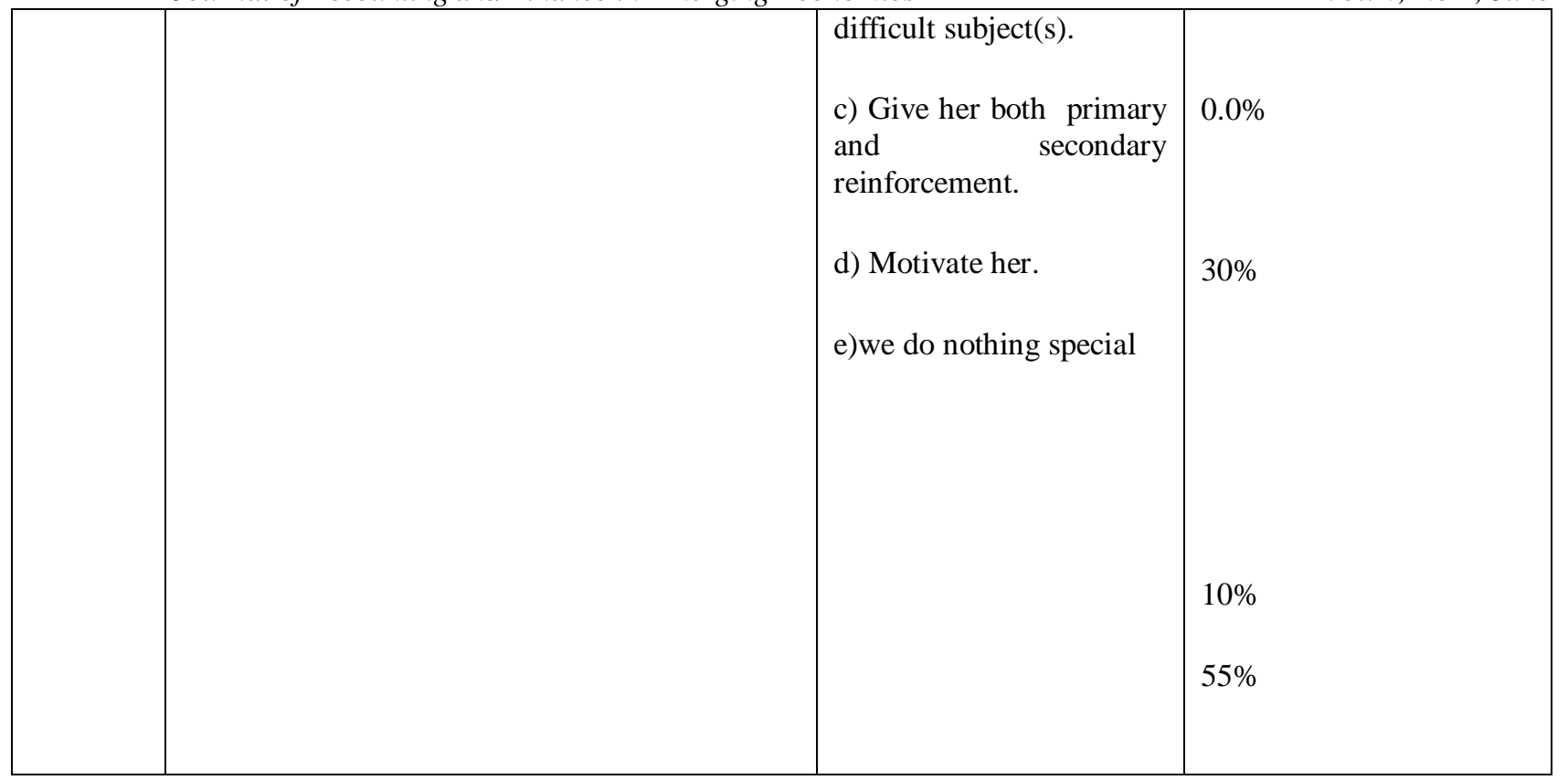

The above table shows lack of appropriate system to deal with violence related events in the schools. In addition no proper system has been existing to rehabilitate victimized girls in the schools of girls with hearing impairment. Although counseling services are available in some institutions but no service is available especially for academic rehabilitation of victimized girls.

\section{Ethical Considerations}

There are some ethical considerations that a researcher has to follow during the interaction with research participants. The fundamental ethical principle is to obtain permission from respondents and inform them about what they are being asked to participate in. Therefore, their consent was obtained from the participants by informing them about the purposes and specifics of the study. The date and time for interview was decided in accordance with respondents' will. The respondents were made fully aware of the study and its purposes by the researchers at the beginning of the interview. They were also informed about the expected duration of an interview and that they were free to withdraw at any stage without giving a reason. The names, class and school of research participants was also protected. Security of the data is also assured by the researchers.

\section{Limitations of the Study}

Due to the sensitivity of the topic of study, the number of sample was limited up to the 17 girls with hearing impairment only, after assuring that their identity and the whole information will remain secret and intact, will be used only for academic purpose. Due to our prevailing social system of stigmatization of victimized girls, some of the respondents could not share the details of the violence related incidents like identity of perpetrator, duration of act etc. Some of the stories are still hidden under social pressure. Only teachers from the schools of victimized girls taken as sample of the study, hence 50 teachers were selected from 17 schools. There is no harm in telling that collection of data was a difficult task to get maximum of information. So the findings of the teachers should generalize carefully.

\section{Discussion}

The present study was an effort to explore the violence experienced by the girls with hearing impairment in the school premises and to see its impact on their education. The girls with hearing impairment have narrated four types of violence they are experiencing in the school including physical, psychological, sexual and verbal(Longobardi, Prino, Fabris, \& Settanni, 2019). The most frequent form of violence reported by the participants was emotional abuse (Pollard, Jr, Sutter, \& Cerulli, 2014; Sebald, 2008), then physical or verbal. The girls have reported experiencing emotional abuse as a consequences of any type of physical, verbal or sexual abuse students reporting experiencing psychological abuse. The findings of the study are in line with the research conducted by Avant, Swopes, Davis, and Elhai (2011) and Black, Sussman and Unger (2010). 
Most of the girls have reported that the perpetrator was intimate and known to them like class fellows, peers and in case of physical and verbal violence, teaching and non-teaching staff. The most frequent forms of violence experience by the girls was kicking, slapping and pushing, or twitching hairs. A study conducted by Cercone et al.'s (2005) have established same results. Sexual violence is also reported by this study. Common form of school based violence reported by the girls were either bad touches, attempt to obtain sexual act, and unwanted sexual comments. The findings of research conducted by Pollard, Sutter, \& Cerulli (2014) are consistent with these findings.

The study highlighted lack of services for the academic rehabilitation of the victimized girls with hearing impairment. Academic rehabilitation is not a one man job, it needs a system of counselling and guidance for the victim to bring them out from the trauma and enabling them to struggle once again for their academic success. The study highlighted that girls who experienced violence in school settings, their promise of pleasure of learning, turn into, fear and pain. A study conducted by UNICEF (2016) has same findings. Our study has further explored that our schools does not have violence protection program. Whereas according to Mytton, DiGuiseppi, Gough, Taylor, \& Logan, (2002) school based violence protection program are exists in developed countries.

\section{Conclusion}

Although the study has found that many girls with hearing impairment are exposed to different forms of violence and harassment in school settings, findings indicates that girls of grade 6 to onward are at greater risk of physical, verbal, sexual and psychological abuse.

However, most of the events of violence in schools remain unreported due to authoritarian system of schools. Girls fear of complaining violence acts against teachers, class-fellows, older peers and staff. Sexual violence or abuse in particular remain hidden.

So there is need to devise a system not only to minimize such events, rather empower the girls to speak against such activities. The study recommended a need to develop a school based violence protection program (SBVP) as it is existing in developing countries. Lastly, study has also raised a question for stake holders to where these girls should go to regain their lost confidence to perform better academically? Who is responsible to normalize these girls socially and academically?

\section{Recommendations of the Study}

Keeping in view findings of the study, the study recommended a need to aware and educate the school going girls with disabilities to on all types of violence and how to keep them safe from such incidents. Further, girls should be empowered and encouraged to speak against such events.

There is also dire need to instruct the school authorities to build a cell in their school only for the dealing of violence related events

\section{References}

Avant, E., Swopes, R., Davis, J., \& Elhai, J. (2011). Psychological abuse and posttraumatic stress symptoms in college students. Journal of Interpersonal Violence, 26, 3080-3097.

Balogh, R., Bretherton, K., Whibley, S., Berney, T., Graham, S., Richold, P., et al. (2001). Sexual abuse in children and adolescents with intellectual disability. Journal of Intellectual Disability Research, 45, 194-201.

Castelino, T and Whitzman ,C.C (2008) The rhetoric and reality of preventing family violence at the local governance level in Victoria, Australia. Journal of Family Studies 14(2-3): 310-321.

Cercone, J., Beach, S., \& Arias, I. (2005). Gender symmetry in dating intimate partner violence: Does similar behavior imply similar constructs? Violence and Victims, 20(2), 207-218.

Dillon, G. Hussain, R., Koxton, D.\& Rehman,S.(2013)Mental, and Physical Health and Intimate Partner Violence against Women: A Review of the Literature. International journal of family medicine, Volume 2013 (2013), Article ID 313909, 15 pages. Retrieved from http://dx.doi.org/1155/2013/313909

Dupper,D.R.\&Adams,N.M.(2002) Low level violence ; A neglected aspect of school culture. Online Journal, volume 37,issue3 pp 350-364.DOI: https://doi.org/10.1177/00485902037003003

Hague, G. \& Sardinha,L.(2010)Violence against women: Devastating legacy and transforming services. Journal of psychiatry, psychology and law.17(4),pp 330-322.

Jaysingh,S.,Jaywardena,P.,\&Perera,H.(2009)Influence of intimate partner violence on behavior, psychological 
characteristics and school performance in Sri Lanka. Journal of Family Studies, 15;274-283.

Khan, H. H. \&Fatima, H(2015)Impact of Domestic, Physical and Psychological violence on the personality of Women .Unpublished thesis of M.Sc, Department of Gender Studies, University of the Punjab, Lahore

Little, L. (2004). Victimization of children with disabilities. In K. A. Kendall-Tackett (Ed.),Health consequences of abuse in the family: A clinical guide for evidence-based practice (pp. 95-108). Washington, DC, USA: American Psychological Association.

MacMillan, R. (2001). Violence and the life course: The consequences of victimization for personal and social development. Annual Review of Sociology, 27, 1-22.

Martin, S. L., Ray, N., Sotres-Alvarez, D., Kupper, L. L., Moracco, K. E., \& Dickens, P. A., et al. (2006). Physical and sexual assault of women with disabilities, violence against Women, 12,823-837.

McCarthy, M. (2001). Sexual violence against women with learning disabilities. Feminism \& Psychology, 8, 544551.

Melissa, L., Anderson, Caroline, M.,\& Kobek Pezzarossi(2014). Violence Against Deaf Women: Effect of Partner Hearing Status, The Journal of Deaf Studies and Deaf Education.19 (3),pp, 411421, https://doi.org/10.1093/deafed/ent053

Moores,D.F.(2006)Educating the deaf: theory and principles $\left(6^{\text {th }}\right.$ Ed.).(USA)

Mytton, J.A., DiGuiseppi, C., Gough, D.A., Taylor, R.S., \& Logan, S. (2001). School-Based Violence Prevention Programs: Systematic Review of Secondary Prevention Trials. Arch Pediatr Adolesc Med. 2002; 156(8), pp,752-762. doi:10.1001/archpedi.156.8.752

Newman, E., Christopher, S. R., \& Berry, J. O. (2000). Developmental disabilities, trauma exposure, and posttraumatic stress disorder. Trauma, Violence, \& Abuse, 1, 154-170.CrossRefGoogle Scholar

Olweus, D., Limber, Susan, P.(2010) Bullying in school: Evaluation and dissemination of the Olweus bullying prevention Program. American Journal of Orthopsychiatry, Vol 80(1), 124134. http://dx.doi.org/10.1111/j.1939-0025.2010.01015.x

Oosterhoorn, R., \& Kendrick, A. (2001). No sign of harm: Issues for disabled children communicating about abuse. Child Abuse Review, 10, 243-253.

Opsahl, N., \& Pick, L. H. (2017). Understanding The Sexual Assault Disclosure Experiences Of Deaf Women. JADARA, 51(3), 44-67.

Ortoleva,S.\& Lewis,H.(2014). Forgotten sisters, a report on violence against women with disabilities: an overview of its nature, scope, causes and consequences. Northeastern University School of Law Research Paper No. 104 2012. Retrieved fromhttps://papers.ssrn.com/sol3/papers.cfm?abstract_id=2133332 on February, 11, 2017.

Paul.V.P.(2000).Language and deafness. USA:

Pollard, R. Q., Jr, Sutter, E., \& Cerulli, C. (2014). Intimate partner violence reported by two samples of deaf adults via a computerized American Sign Language survey. Journal of interpersonal violence, 29(5), 948-965. doi: $10.1177 / 0886260513505703$.

Rice, M. L., Hadley, P. A., \& Alexander, A. L. (1993). Social biases toward children with speech and language impairments: A correlative causal model of language limitations. Applied Psycholinguistics, 14, 445471. CrossRefGoogle Scholar

Schenkel, L.S., Rothman-Marshall, G., Schlefer, D.A., Towne, T.L., Brunash, D.L, Priddy, B.M. (2014). Child maltreatment and trauma exposure among deaf and hard-of-hearing young adults. Child Abuse \& Neglect, 38(10), 1581-1589.

Schild, S., Dalenberg, C. (2015). Consequences of child and adult sexual and physical trauma among deaf adults. Journal of Aggression, Maltreatment, \& Trauma, 24(3), 237-256.

Schofield, M. and Walker, R. (2008) 'Innovative approaches to family violence'. Journal of Family Studies. 14(2\&3): (PDF Download Available). Available from: https://www.researchgate.net/publication/236274200_Schofield_M_and_Walker_R_2008_Innovative_approa ches_to_family_violence'_Journal_of_Family_Studies_1423 [accessed Jul 9, 2017].

Sebald, A. (2008). Child Abuse and Deafness: An Overview. American Annals of the Deaf, 153(4), 376-383. Retrieved from http://www.jstor.org/stable/26234534

Sharon, W. S. (2015) Psychology and Behavioral Health, Edition: 4th, Chapter: Volume 5 Essay: Emotional Abuse, Publisher: Salem Press at Grey house Publishing

Smith,K.P.\&Brain,P.(2000).Bullying in schools: Lessons for two decades of research. Aggressive 
Behaviour, Volume,26,pp 1-9.

Sobsey, D. (2002). Exceptionality, education, and maltreatment. Exceptionality, 10, 29-46.CrossRefGoogle Scholar

Sobsey, D., \& Doe, T. (1991). Patterns of sexual abuse and assault. Sexuality and Disability, 9,243259. CrossRefGoogle Scholar

Sobsey, D., Randall, W., \&Parrila, R. K. (1997). Gender differences in abused children with and without disabilities. Child Abuse \& Neglect, 21, 707-720.CrossRefGoogle Scholar

Sullivan, P., \& Knutson, J. (2000). Maltreatment and disabilities: A population-based epidemiological study. Child Abuse \& Neglect, 24, 1257-1273.CrossRefGoogle Scholar

Sullivan, P., \& Knutson, J. (2000). Maltreatment and disabilities: A population-based epidemiological study. Child Abuse \& Neglect, 24, 1257-1273.CrossRefGoogle Scholar

Tary. J., Toban \& George. M. Sugal (1999) Journal of emotional and behavioral disorders,

Using Sixth-Grade School Records to Predict School Violence, Chronic Discipline Problems, and High School Outcomes Volume: 7 issue: 1, page(s): 40-53, DOI: https://doi.org/10.1177/106342669900700105

Violence against children in education setting in south Asia, a desk review (2016).Published by UNICEF ROSA.

Weiner, M.T.\&Miller, M.(2006)Deaf children and bullying: directions for future research. Ann Deaf, Spring(1), 6170.

World Health Organization (2013).Responding to intimate partner violence and sexual violence against women with disabilities, WHO clinical and policy guideline. WHO library cataloguing data.

World Health Organization. (1990). Composite international diagnostic interview (CIDI): CIDI-interview, CIDIuser manual, and CIDI-computer programs. Geneva, Switzerland:

Bond, L., Butler, H., Thomas, L., Carlin, J., Glover, S., Bowes, G., \& Patton, G. (2007). Social and school connectedness in early secondary school as predictors of late teenage substance use, mental health, and academic outcomes. Journl of Adolescent Health, 40(4), 357. e359-357. e318.

Davies, S. E., \& True, J. (2015). Reframing conflict-related sexual and gender-based violence: Bringing gender analysis back in. Security Dialogue, 46(6), 495-512.

Dupper, D. R., \& Meyer-Adams, N. (2002). Low-level violence: A neglected aspect of school culture. Urban Education, 37(3), 350-364.

Han, L., You, D., Gao, X., Duan, S., Hu, G., Wang, H., . . . Zeng, F. (2019). Unintentional injuries and violence among adolescents aged 12-15 years in 68 low-income and middle-income countries: a secondary analysis of data from the Global School-Based Student Health Survey. The Lancet Child \& Adolescent Health, 3(9), 616626.

Khoury-Kassabri, M. (2019). School violence is a major subject of concern for students, parents, school staff, and the general public, especially because of its adverse impact on students' physical and emotional well-being and academic performance (Khoury-Kassabri, Benbenishty, Astor, \& Zeira, 2004; Mishna, 2012). Mental Health and Palestinian Citizens in Israel, 278.

Longobardi, C., Prino, L., Fabris, M. A., \& Settanni, M. (2019). Violence in school: an investigation of physical, psychological, and sexual victimization reported by Italian adolescents. Journal of school violence, 18(1), 4961.

Macmillan, R. (2001). Violence and the life course: The consequences of victimization for personal and social development. Annual review of sociology, 27(1), 1-22.

Macmillan, R., \& Hagan, J. (2004). Violence in the transition to adulthood: Adolescent victimization, education, and socioeconomic attainment in later life. Journal of research on adolescence, 14(2), 127-158.

Taiwo, P. A. (2019). Underdeveloping the Disadvantaged: The Dilemma of Globalization on Women in a Developing Country.

Thornberg, R. (2011). 'She's weird!'-The social construction of bullying in school: A review of qualitative research. Children \& society, 25(4), 258-267.

van der Heijden, I., Abrahams, N., \& Harries, J. (2019). Additional layers of violence: the intersections of gender and disability in the violence experiences of women with physical disabilities in South Africa. Journal of interpersonal violence, 34(4), 826-847. 